\title{
Knowledge Areas Necessary for Successful NCAA Division III Certified Athletic Trainers: NCAA Division III Certified Athletic Trainers' Perceptions
}

\author{
by \\ Robert Schneider ${ }^{1}$
}

\begin{abstract}
NCAA Division III head certified athletic trainers (ATCs) ( $n=185)$ were surveyed to determine knowledge areas needed by ATCs to be successful as Division III ATCs. A Likert-like scale survey consisted of 12 athletic training related knowledge areas and included the following five point scale: essential, very important, important, not very important, and irrelevant. Findings indicated that it is important that Division III ATCs have all 12 knowledge areas to be successful. Although injury-related knowledge areas were considered essential, all of the knowledge areas were at least considered important to the success of ATCs, and none were considered irrelevant. Those involved in athletic training curricular issues should place or continue to place the most emphasis on areas related to injuries.
\end{abstract}

Key words: sport injuries, athletic trainers, education programs, survey

\section{Introduction}

\section{NCAA Division III Certified Athletic Trainers' Perceptions}

Participation in organized sport has never been higher, and opportunities to play have never been greater (Dillon, 2006). With increased sport participation rates has come an increase in sport-related injuries. Dillon contended that about half of all injuries in organized sports could be prevented if more attention were paid to more qualified staff. Carefully screening and hiring certified athletic trainers (ATCs) might be one way to help ensure for the proper care of injured athletes. Certified athletic trainers, however, can only succeed if they are educated in the proper knowledge areas.

After determining which knowledge areas are important for ATCs, the standardization of curricula in athletic training educational preparation programs can be established and continually updated. By using empirical research as a basis for the establishment and standardization of necessary knowledge areas for ATCs, ultimately students will be better prepared to gain employment. Peer and Rakich (2000) pointed out that securing a strong position in the highly competitive allied health care market will be facilitated by standardizing the educational preparation of entry-level ATCs through accreditation.

Following the completion of coursework and clinical experiences in athletic training education programs, students are required to pass the National Athletic Trainer's Association Board of Certification (NATABOC) exam before practicing their skill and caring for athletes in a sport program. Practicing ATCs will only be successful if they master the knowledge areas determined to be essential to the field of athletic training. The success of ATCs partly

1 - Department of Physical Education and Sport, The State University of New York at Brockport, USA 
depends on the knowledge they gain and carry with them into employment settings from athletic training education programs. If appropriate knowledge areas can be identified that are essential for the success of ATCs, athletes in sport programs will benefit from improved care, as will the allied health care industry as a whole.

The process of determining effective knowledge areas for athletic training education programs is an ongoing process that should be developed based on consideration and input from a variety of sources, including ATCs at institutions of higher education. The purpose of this study was to determine and classify the importance of various knowledge areas related to successful athletic training practice at the Division III level as perceived by practicing Division III head ATCs.

\section{Related Literature}

\section{Evolution of Knowledge Areas}

Delforge and Behnke (1999) traced the history and evolution of athletic training in the United States since the founding of the National Athletic Trainer's Association (NATA) in 1950. Since 1950, an identifiable body of knowledge has evolved and become recognized by the NATA as content areas required by athletic training education programs to gain program approval through NATA. As part of the early curricular process, in 1968, William E. Newell, chairman of a NATA subcommittee on curricular developments, appointed a subcommittee that designed a questionnaire to determine whether or not institutions offered a curriculum that fulfilled the requirements of the NATA approved program of education (Delforge and Behnke).

Shortly thereafter, curriculums of four institutions were the first to receive approval by the NATA's Board of Directors: Indiana State University, Lamar Tech, Mankato State College, and New Mexico University (Miller, 1999). Since the first four program approvals, ATC education has evolved from a quantitative experience, which essentially equated to a specific number of hours of observation to a more "outcome-based" experience which requires specific outcomes to be met (Washington-Lofgren, Westerman, Sullivan, \& Nashman, 2004).

\section{Sciences}

Athletic trainers, according to Dillon (2006), must attain undergraduate degrees that typically traverse pre-med disciplines like kinesiology, anatomy, and epidemiology. In their description of the history of athletic training education programs throughout the United States, Delforge and Behnke (1999) showed the consistent presence of science courses throughout the evolution of athletic training curriculums.

\section{Pedagogy}

Eventually, the attempt to make a rational argument for the inclusion of a critical pedagogy into the field of athletic training education was made (Geisler, 2003). Athletic training educators are pedagogically situated and some may be expected to embrace the historical and intellectual purposes associated with higher education and the world of academia. In this light, Geisler advocated for meaningful and critical learning experiences that assist in the transformation of athletic training students into proactive and authentically democratic citizens.

\section{Nutrition}

Given the many primary responsibilities designated to ATCs, nutrition is understandably considered a secondary responsibility by athletic trainers (Rockwell, Nickols-Richardson, \& Thye, 2001). However, if athletes are not provided with nutritional advice, they will likely continue to depend on their coaches and ATCs for information and guidance. Rockwell et al. also suggested that additional nutritional education requirements might be warranted for ATCs because athletes will inevitably rely on trainers for advice related to nutrition.

\section{Psychosocial}

Fisher and Wrisberg (2004) discussed the need for ATCs to be adept in dealing with athletes in psychologically positive ways. In particular, Fisher and Wrisberg talked about the role that psychological factors can play in injury susceptibility and recovery. In a study that surveyed male and female college soccer players who had been treated for an injury throughout the course of one academic year, Washington-Lofgren et al. (2004) found that athletes believed that ATCs are more effective when including a psychological aspect to the recovery process. Robbins and Rosenfeld (2001) surveyed 35 male and female Division I collegiate athletes from various sports, and their findings confirmed the positive effects of ATCs' social support on injured athletes' recovery efforts. 


\section{Risk Management/Liability}

Chen and Esposito (2004) highlighted the increased importance of risk management knowledge to ATCs as the managerial responsibilities have increased, and they also examined the areas of liability that ATCs may face in their delivery of care. Swann and Carr (2006) underscored the importance of structured policies pertaining to risk management that allowed athletic training education programs to adhere to a high standard of care for both students and clinicians. Finally, Lyznicki, Riggs, and Champion (1999) discussed liability issues in sport and the notion that injury is an inherent risk of athletic competition.

\section{Methods}

\section{Subjects}

The subjects in this study were ATCs of all NCAA Division III colleges and universities, totaling 410. Of the 410 subjects receiving surveys, $185 \mathrm{com}$ pleted and returned them for a return rate of $45.1 \%$.

\section{Survey}

A 12 statement Likert-like scale survey was used to determine knowledge areas necessary for successful Division III ATCs as perceived by Division III ATCs. Content validity of the survey was partially based on the expertise of the researchers (one of whom was a Division III head ATC), and current literature pertaining to knowledge areas related to athletic training. Also helping to address content validity of the survey was the fact that the survey was based in part on the standards for the accreditation of entry-level athletic training education programs (Commission on Accreditation of Athletic Training Education [CAATE], 2006).

The knowledge areas of the study was delimited to only those knowledge areas that pertained to the following 12 areas: evaluation of staff, general legal issues, care of equipment and supplies, prevention of injuries, recognition of injuries, management of injuries, treatment of injuries, rehabilitation of injuries, sport nutrition for athletes, sport psychology for athletes, fitness and conditioning for athletes, and safety and risk management for athletes. This study did not examine non-planned learning experiences. The Likert-like scale presented to the Division III head ATCs consisted of the following choices: (5) es- sential, (4) very important, (3) important, (2) not very important, and (1) irrelevant.

\section{Procedures}

After receiving Internal Review Board (IRB) approval through the researchers' educational institution, the survey was prepared for mailing. The subjects were mailed the survey, along with a cover letter describing the survey and the procedure for completing and returning it. The cover letter stated that the subjects' response to the survey was optional and assured the identities and institutions of those who chose to respond would remain anonymous. Regarding each of the 12 statements related to knowledge areas, respondents were asked to circle one of the five Likert-like scale choices that followed each statement. The subjects were provided with a self-addressed envelope for return of the survey.

The purpose of this study was to determine and classify the importance of various knowledge areas related to successful athletic training practice at the Division III level as perceived by practicing Division III head ATCs. Perceptions regarding selected knowledge areas were sought from NCAA Division III head ATCs.

\section{Results}

The mean percentages of NCAA Division III head ATCs and the rate at which they believed knowledge areas were essential, very important, important, not very important, or irrelevant for successful NCAA Division III ATCs were compiled. Overall, the NCAA Division III head ATCs deemed all 12 of the knowledge areas at least important to the success of Division III ATCs. Of the 12 knowledge areas, those that were related to injuries were clearly believed to be more essential to the success of the Division III ATCs than the other knowledge areas. None of the 12 knowledge areas were considered irrelevant.

All five knowledge areas related to injuries (Table 1) were considered essential to the success of Division III intercollegiate ATCs $(\mathbf{n}=\mathbf{1 8 5})$ by at least $60 \%$ of the subjects. The specific injury-related knowledge areas and the rate of subjects considering them to be essential were as follows: recognition of injuries $(79.0 \%)$, management of injuries $(77.3 \%)$, treatment of injuries $(77.3 \%)$, rehabilitation of injuries $(69.8 \%)$, and prevention of injuries $(61.7 \%)$. When collapsing the essential category with the very important category, all six of the aforementioned 


\begin{tabular}{|c|c|c|c|c|c|}
\hline \multicolumn{6}{|c|}{ Injury Areas Necessary for NCAA Division III ATC Succes } \\
\hline $\begin{array}{c}\text { Injury } \\
\text { Knowledge Area }\end{array}$ & Essential & $\begin{array}{c}\text { Very } \\
\text { Important } \\
\end{array}$ & Important & $\begin{array}{l}\text { Not Very } \\
\text { Important }\end{array}$ & Irrelevant \\
\hline $\begin{array}{l}\text { Prevention of } \\
\text { Injuries }\end{array}$ & 61.7 & 32.4 & 2.7 & 0.5 & 2.7 \\
\hline $\begin{array}{l}\text { Recognition of } \\
\text { Injuries }\end{array}$ & 79.0 & 17.3 & 0.5 & 0.0 & 3.2 \\
\hline $\begin{array}{l}\text { Management of } \\
\text { Injuries }\end{array}$ & 77.3 & 18.4 & 1.1 & 0.5 & 2.7 \\
\hline $\begin{array}{l}\text { Treatment of } \\
\text { Injuries }\end{array}$ & 77.3 & 19.0 & 0.5 & 0.5 & 2.7 \\
\hline $\begin{array}{l}\text { Rehabilitation of } \\
\text { Injuries }\end{array}$ & 69.8 & 24.3 & 2.7 & 0.5 & 2.7 \\
\hline
\end{tabular}

injury-related categories were believed to be essential or very important by at least $94 \%$ of the respondents.

Seven general knowledge areas necessary for success of Division III ATCs are displayed in Table 2 $(\mathrm{n}=185)$. Three knowledge areas that were somewhat balanced across the three response options of essential, very important, and important were knowledge of general legal issues, fitness and conditioning for athletes, and safety and risk management of athletes. Of these three categories, safety and risk management were rated more essential $(44.9 \%)$ and very important (42.2\%) than the other two. General legal issues were perceived to be essential by $28.6 \%$, very important by $42.2 \%$, and important by $26.0 \%$. And, fitness and conditioning were considered to be essential by $21.6 \%$, very important by $53.0 \%$, and important by $21.6 \%$ of the respondents.

Some of the knowledge areas, however, were considered less essential than others. The ability to evaluate staff members was considered to be essential by $10.3 \%$ of the respondents and $17.3 \%$ considered knowledge of sport psychology for athletes as essential. Even though having the ability to evaluate staff was considered essential by $10.3 \%$ of the re- spondents, $44.9 \%$ considered it very important, and $36.2 \%$ considered it important. When collapsing the three categories of essential, very important and important, it was found that $91.4 \%$ of indicated respondents felt the ability to evaluate staff members was at least an important knowledge area for the success of Division III ATCs. Similarly, knowledge of sport nutrition for athletes was considered essential by $23.2 \%$ of the respondents, but more than half (50.9\%) believed it to be very important, and almost one-fourth $(24.3 \%)$ believed it to be important. Although only $24.3 \%$ indicated that knowledge related to caring for equipment and supplies was important, well over a majority $(54.5 \%)$ believed it to be very important.

\section{Discussion}

As indicated in the Results section of this study, knowledge related to injuries was perceived by respondents to be the most essential cognate for ATCs to succeed as a Division III ATC. This finding concurs with most athletic training related literature which predominately addresses topics related to injuries.

\begin{tabular}{|cccccc}
\hline \multicolumn{7}{c}{ General Knowledge Areas Necessary for NCAA Division III ATC Success } & Table 2 \\
\hline General Knowledge Area & Essential & Very Important & Important & Not Very Important & Irrelevant \\
\hline Evaluation of Staff & 10.3 & 44.9 & 36.2 & 7.0 & 1.6 \\
General Legal Issues & 28.6 & 42.2 & 26.0 & 0.5 & 2.7 \\
Equipment \& Supplies Care & 24.3 & 54.5 & 16.8 & 2.2 & 2.2 \\
Sport Nutrition & 23.2 & 50.9 & 23.2 & 2.2 & 0.5 \\
Sport Psychology & 17.3 & 44.9 & 33.0 & 3.2 & 1.6 \\
Fitness \& Conditioning & 21.6 & 53.0 & 21.6 & 2.2 & 1.6 \\
Safety \& Risk Management & 44.9 & 42.2 & 9.7 & 0.0 & 3.2 \\
\hline
\end{tabular}


The knowledge areas in this study were similar to, but not directly related to, the educational competencies for athletic training developed by the NATA and the standards required for the accreditation of entry-level athletic training education programs developed by the CAATE (2006). Nevertheless, the overall findings in this study were found to be supportive of the educational competencies and standards developed by the NATA and CAATE, which also place a high emphasis on injury-related and treatment-related skills. Essentially, Division III ATCs support of the knowledge areas in this study may indicate that they are also supportive of the CAATE's educational competencies, which, in part, were established to provide curricular guidelines for entry-level athletic training education programs interested in preparing entry-level ATCs and achieving program accreditation through the CAATE.

\section{Nutrition}

Although this study showed nutrition to be an important area of knowledge for the success of Division III ATCs, mastering the knowledge area of nutrition may be overly demanding, given that nutrition is a comprehensive, independent area of study. Consideration might be given to allowing qualified sport nutrition professionals to advise athletes in that area. Rockwell et al. (2001) provided evidence of the breadth of responsibilities undertaken by sport nutritionists in athletic departments by providing the following list of duties: individual athlete counseling regarding meal planning, nutrient needs, eating behaviors/concerns, weight loss and gain, diet and body composition analysis, staff and athlete education about nutrition supplements, and other nutrition-related topics; as well as coach and trainer assistance with meal planning for training, composition, and on-campus meals; and support systems referral and collaboration. In addition to effectively adhering to the ATCs current duties, it would be unreasonable to expect ATCs to also effectively perform the aforementioned nutritionist duties.

\section{Psychological and Rehabilitation}

Although $17.3 \%$ of respondents rated knowledge of sport psychology for athletes as essential, an overwhelming rate of $95.2 \%$ of the ATCs considered it at least important for successful Division III ATCs. In agreement with the findings of this study were Washington-Lofgren et al. (2004), who found it ap- propriate for ATCs to assist athletes in the psychological recovery during rehabilitation.

Further supporting the finding in this study that sport psychology is important for the success of ATCs was Milne, Hall, and Forwell (2005), who emphasized the importance of self-efficacy and coping strategies for effective injury rehabilitation. Support was also pointed out to be important for effective injury rehabilitation (Gould, Udry, Bridges, \& Beck, 1997; Ford \& Gordan, 1999). Results of a study by Johnston and Carroll (2000) further affirmed the importance of problem-focused coping for effective recovery of injured athletes. Clearly ATCs play an important role in assisting athletes with development of coping behaviors for effective injury recovery.

\section{Risk Management/Liability}

This study found that knowledge areas of legal liability, and safety and risk management were perceived as very important for Division III ATCs. Researchers who conducted other studies also found these knowledge bases to be important. Gould and Deivert (2003) pointed to the importance of hiring an ATC to help reduce the risk and to help allay the serious concerns with legal liability issues in interscholastic sport settings. Also supporting the importance of risk management as a very important knowledge area for the success of ATCs were Lyznicki et al. (1999), who found the implementation of risk management programs by ATCs to be important in minimizing liability in secondary schools. Chen and Esposito (2004) recognized the importance of risk management and acknowledged the need for ATCs to formulate risk management plans.

\section{Recommendations for Future Research}

In an editorial Casa (2005) supported continued empirically based research regarding athletic training curriculum by stating, "Every course an athletic training student takes should be peppered with honest assessments of the actual evidence to support the topics being covered" (p. 138). The importance of identifying appropriate knowledge areas was also reinforced by Kahanov and Andrews (2001), who found that educational experiences were a salient factor related to criteria important to hiring ATCs.

To effectively conduct continued research related to athletic training knowledge areas and curriculum, additional populations should be surveyed. In doing so, broader insights will be gained related to knowledge areas necessary for successful ATCs. The au- 
thors of this study recommend that populations be surveyed beyond NCAA Division III, including but not limited to ATCs at various intercollegiate and professional levels. Various athlete populations should also be surveyed.

\section{Conclusions}

Given that the 12 areas of knowledge in this study were generally viewed as being essential, very important or important for successful ATCs at the Division III level, these 12 areas should reasonably be considered as focal points of athletic training curricula. Also, since these 12 areas of knowledge are similar to the current curricular standards of the NATA, the findings of this study reinforce the appropriateness of the current curricular standards. The NATA administrators, heads of athletic trainer educational programs, athletic training professors and instructors, and even students in athletic training education programs would be well served to stress all 12 of the knowledge areas examined in this study.

Studies such as this one, which examine knowledge areas pertinent to the field of athletic training, contribute to the information base that is needed to develop curriculums in educational programs that, in the end, are responsible for producing successful ATCs. Furthermore, research of selected knowledge areas may initiate dialogue related to the ongoing process of determining the most essential and effective knowledge areas necessary for ATCs to have in order to be successful. Dialogue that comes from the findings of this study may serve as a starting point for support or change of curricular-related aspects of athletic training education programs.

\section{References}

Casa, D.J. Question everything: The value of integrating research into an athletic training education. J Athl Training, 2005. 40(3): 138.

Chen, S., Esposito, E. (2004). Practical and critical legal concerns for sport physicians and athletic trainers. Sport Journal, 7(2), Retrieved December 3, 2008, from http://www.thesportjournal.org/2004Journal/Vol7No2/ChenEsposito.asp

Commission on Accreditation of Athletic Training Education. (2006, June 8). Standards for the accreditation of entry-level athletic training education programs. Retrieved December 1, 2008, from: http://caate.net/ss docs/standards.6.8.2006.pdf

Delforge, G.D., Behnke, R.S. The history and evolution of athletic training education in the United States. J Athl Training, 1999. 34(1): 53-61.

Dillon, N. (2006). Keeping student athletes safe. American School Board Journal, 193(8), 15-19.

Fisher, L.A., Wrisberg, C.A. A "positive" psychology of athletic training. Athlet Ther Today, 2004. 9(3), 58-59.

Ford, I.W., Gordan, S. (1999). Coping with sport injury: Resource loss and the role of social support. Journal of Personal and Interpersonal Loss, 1999. 4(3), 243-256.

Gardiner, A., Mensch, J.M. Promoting professional development in athletic training. Athlet Ther Today, 2004. 9(4), 30-31.

Geisler, P.R. Multiculturalism and athletic training education: Implications for educational and professional progress. J Athl Training, 2003. 38(2), 141-151.

Gould, D., Udry, E., Bridges, D., \& Beck, L. Coping with season-ending injuries. The Sport Psychologist, 1997. 11(4), 379-399.

Gould, T.E., Deivert, R.G. Secondary-school administrators' knowledge and perceptions of athletic training. Athlet Ther Today, 2003. 8(1), 57-62.

Johnston, L.H., \& Carroll, D. Coping, social support, and injury: Changes over time and the effects of level of sports involvement. J Sport Rehabil, 2000. 9(4), 290-303. 
Kahanov, L., Andrews, L. A survey of athletic training employers' hiring criteria. J Athl Training, 2001. 36(4), 408412.

Lyznicki, J.M., Riggs, J.A., Champion, H.C. Certified athletic trainers in secondary schools: report of the council on scientific affairs, American Medical Association. J Athl Training, 1999. 34(3), 272-276.

Miller, S.J. Approval of athletic training curriculums at colleges and universities. J Athl Training, 1999. 34(1), 62-63.

Milne, M., Hall, C. Forwell, L. Self-efficacy, imagery use, and adherence to rehabilitation by injured athletes. J Sport Rehabil, 2005. 14(2), 150-167.

Peer, K.S., Rakich, J.S. Accreditation and continuous quality improvement in athletic training education. J Athl Training, 2000. 35(2), 188-193.

Robbins, J.E., Rosenfeld, L.B. Athletes' perceptions of social support provided by their head coach, assistant coach, and athletic trainer, pre-injury and during rehabilitation. Journal of Sport Behavior, 2001. 24(3), $277-297$.

Rockwell, M.S., Nickols-Richardson, S.M., Thye, F.W. Nutrition knowledge, opinions, and practices of coaches and athletic trainers at a Division I University. Int J Sport Nutr Exer Metab, 2001. 11(2), 174-185.

Swann, E., Carr, D.W. Managing risk in an athletic training education program. Athlet Ther Today, 2006. 11(1), 1721.

Washington-Lofgren, L., Westerman, B.J., Sullivan, P.A., Nashman, H.W. (2004). The role of the athletic trainer in the post-injury psychological recovery of collegiate athletes. International Sports Journal, 2004. 8(2), 94-104.

\section{Corresponding author}

\section{Robert C. Schneider}

Department of Physical Education and Sport; The State University of New York at Brockport 350 New Campus Drive, Brockport, NY 14420

Phone: 585-395-2587

Fax: 585-395-2771

Work Cell Phone: 585-423-9603

E-mail: rschneid@brockport.edu 